\title{
Expression of Receptors for Glial Cell Line-derived Neurotrophic Factor (GDNF) and Neurturin in the Inner Blood-retinal Barrier of Rats
}

\author{
Yo Igarashi $^{1,2}$, Hideki Chiba ${ }^{1}$, Hiroyuki Utsumi ${ }^{1,3}$, Hideaki Miyajima ${ }^{1,2}$, Tsutomu Ishizaki ${ }^{1,4}$, Tomoko \\ Gotoh $^{1}$, Kazuhide Kuwahara ${ }^{1}$, Hirotoshi Tobioka', Masaaki Satoh ${ }^{5}$, Michio Mori ${ }^{1}$, and Norimasa \\ Sawada ${ }^{*}$ \\ ${ }^{1}$ Department of Pathology, ${ }^{2}$ Department of Ophthalmology, ${ }^{4}$ Department of Neurosurgery, ${ }^{5}$ Department of \\ Clinical Pathology, Sapporo Medical University School of Medicine, South-1, West-17, Chuo-ku, Sapporo \\ 060, Japan, ${ }^{3}$ Present address: Toxicology Laboratories, Yoshitomi Pharmaceutical Industries, Ltd., Yamazaki \\ 214-1, Fukusaki-chou, Kanzaki-gun 679, Japan
}

\begin{abstract}
The retina is protected from somatic circulation by the blood-retinal barrrier (BRB) composed of tight junctions between retinal vascular endothelial cells (the inner BRB) and those between retinal pigment epithelial cells (the outer BRB). Our recent studies showed that glial cell line-derived neurotrophic factor (GDNF) secreted from astrocytes regulates the permeability of the BBB. In the present study, we immunohistochemically examined the expression of GDNF, neurturin (NTN) and their receptors, GFR $\alpha 1$ for GDNF and GFR $\alpha 2$ for NTN, because the capillaries of the inner BRB show specialization very similar to the blood-brain barrier (BBB). GDNF and NTN were detected in glial fibrillary acidic protein (GFAP)-positive cells, including Müller cells. GFR $\alpha 1$ and GFR $\alpha 2$ were localized in von Willebrand factor-positive cells. GDNF and NTN enhanced the barrier function of endothelial cells derived from porcine brain cortex. These results strongly suggest that the barrier function of the BRB is regulated by GDNF and NTN secreted from glial cells, like the BBB.
\end{abstract}

Key words: GDNF/neurturin/Müller cells/blood-retinal barrier/GDNF family receptor $\alpha$ component (GRF $\alpha$ )

The blood retinal barrier (BRB) composed of the inner BRB and the outer BRB has an important role in maintaining the homeostasis of the retina (Chuha-Vaz et al., 1966; ChuhaVaz, 1976). The endothelial cells of the retinal capillaries form the inner BRB and the pigment epithelial cells form the outer BRB. The inner BRB is considered to be almost the same as the blood-brain barrier (BBB) in nature, except for fatty acid transport (Alberghina, 1998). The anatomical structures of the BRB, i.e., well-developed tight junctions, the paucity of pinocytotic vesicles and the intimate relationship between astrocytes and capillaries, are very similar with those of the BBB. Particularly the capillaries in the

\footnotetext{
* To whom all correspondence should be addressed: Department of Pathology, Sapporo Medical University School of Medicine, South-1, West-17, Chuo-ku, Sapporo 060, Japan.

Tel: +81-11-611-2111, ext:2700, Fax: +81-11-613-5665

E-mail: sawadan@sapmed.ac.jp

Abbreviations: BBB, Blood-brain barrier; BRB, Blood-retinal barrier; GDNF, Glial cell line-derived neurotrophic factor; NTN, neuturin; GF, GDNF family; GFR, GDNF family receptor; GFAP, glial fibrillary acidic protein; FITC, fluorescein isothiocyanate; TRITC, tetramethylrhodamine isothiocyanate; PBS, phosphate-buffered saline; TER, transendothelial electrical resistance.
}

retina are surrounded by the end-feet of glial cells, like the BBB. Thus, the glial cells are thought to exert an enhancing effect on the barrier function of the BRB, although the molecular mechanisms have yet to be fully clarified (Small et al., 1993; Tout et al., 1993).

Glial cell line-derived neurotrophic factor (GDNF) and neurturin (NTN) are the first two members of the GDNF family (GF). GDNF is reported to maintain dopaminergic neurons and peripheral motor neurons. Similarly, NTN is reported to have a wide spectrum of biological effects on various kinds of neurons, and its amino acid sequence is 42\% identical to GDNF (Henderson et al., 1994; Kotzbauer et al., 1996; Lin et al., 1993). GDNF and NTN specifically bind to GF family receptor $\alpha$ components 1 and 2 (GFR $\alpha 1$, GFRa2), respectively (Baloh et al., 1998; Durbec et al., 1996; Jing et al., 1996; Treanor et al., 1996; Trupp et al., 1996). Although GDNF and NTN play roles in survival of retinal ganglion cells and the development of the retina (Carwile et al., 1998; Jomary et al., 1999), there are no reports focusing on the relationship between these factors and the BRB. 
Our previous studies demonstrated that capillary endothelial cells forming the BBB have GFR $\alpha 1$ and that the barrier function of the cells is enhanced by GDNF (Igarashi et al., 1999; Yamada-Sasamori et al., 1997). The anatomical similarity between the BBB and the inner BRB prompted us to examine the expression of GDNF, NTN, GFR $\alpha 1$ and GFR $\alpha 2$ immunohistochemically. This is the first report that the BRB is regulated by GDNF and NTN, which are secreted from glial cells in the retina.

\section{Materials and Methods}

\section{Animals}

All procedures were conducted in a manner consistent with the Association for Research in Vision and Ophthalmology Resolution on the Use of Animals in Research. All the animals were given
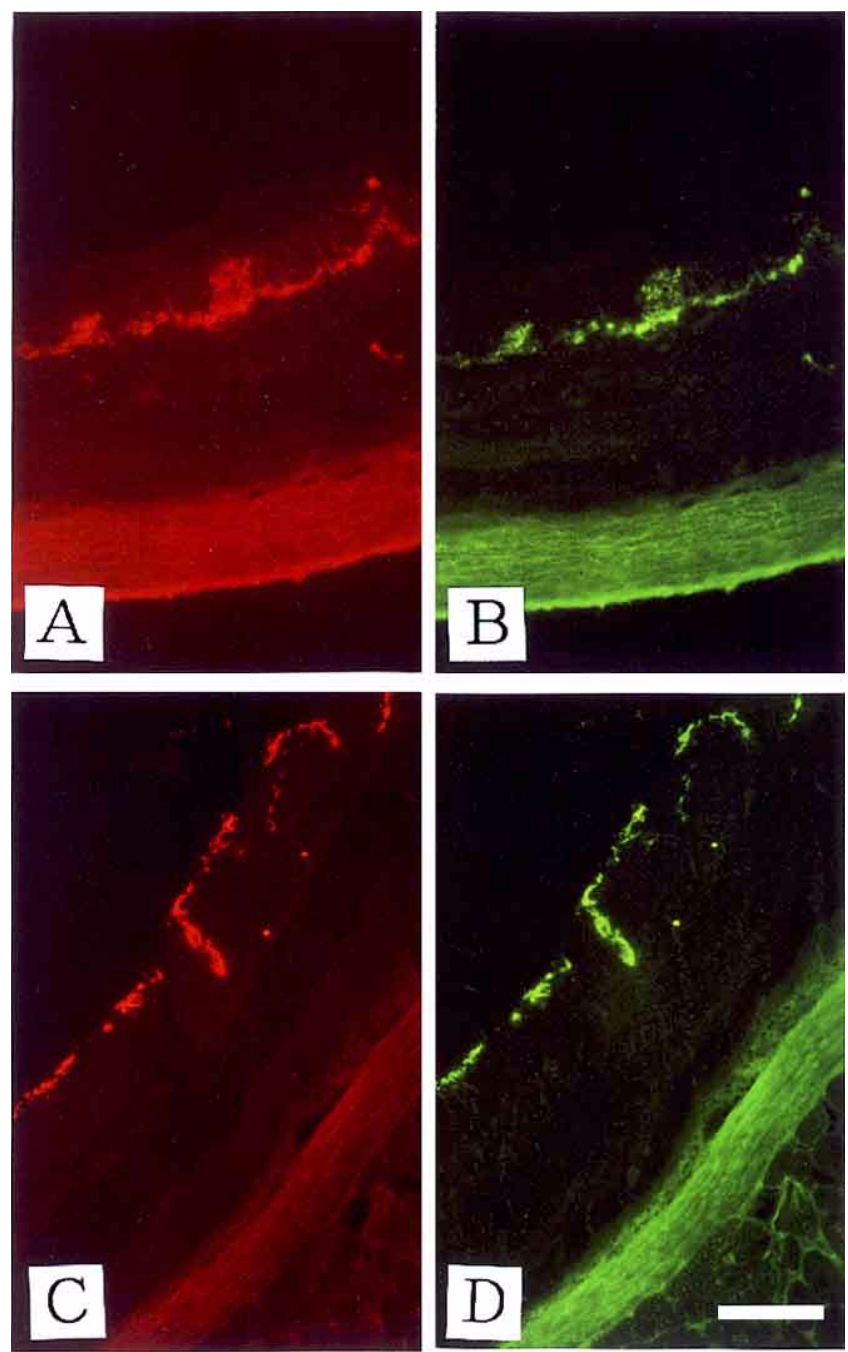

Fig. 1. Double-immunostaining of GDNF and NTN with GFAP A: GFAP, B: GDNF, C: GFAP, D: NTN. Bar: $150 \mu \mathrm{m}$. water and fed ad libitum, and were maintained on a $12 \mathrm{hr}$ light $/ 12 \mathrm{hr}$ dark cycle. Male Sprague-Dawley rats weighing 250-350g were anesthetized with ether and sacrificed by decapitation. The nucleated eyes were immediately embedded in Tissue-Tek Cryomold 1 with O.C.T. compound (Miles Inc., Elkhart, IN, U.S.A.) and stored at $-80^{\circ} \mathrm{C}$ until use. The $6-\mu \mathrm{m}$-thick frozen sections were fixed in cold mixture of methanol and acetone (1:1) for $5 \mathrm{~min}$.

\section{Immunohistochemistry}

Double-immunofluorescent staining was carried out by the sequential incubation of a mixture of primary antibodies raised in different animal species and of a mixture of corresponding speciesspecific secondary antibodies. After rinsing with phosphatebuffered saline (PBS), the slides were incubated overnight with the primary antibody at $4{ }^{\circ} \mathrm{C}$. Primary antibodies used were: rabbit anti-GDNF (1:40), goat anti-GFR $\alpha 1$ (1:40), goat anti-NTN (1:40), goat anti-GFR $\alpha-2$ (1:40), rabbit anti-von Willebrand factor (1:200), rabbit anti-Ret (1:40) (Santa Cruz Biotechnology Inc., CA, U.S.A.) and mouse anti-glial fibrillary acidic protein (GFAP) (1:100) (BioGenex, San Ramon, CA, U.S.A.). Sections were then further incubated with the appropriate secondary antibody (DAKO A/S, Glostrup, Denmark) for $1 \mathrm{hr}$ at room temperature. Fluorescein isothiocyanate (FITC)-conjugated porcine anti-rabbit $\operatorname{lgG}(1: 100)$, FITC-conjugated rabbit anti-goat $\lg \mathrm{g} \quad(1: 100)$, tetramethylrhodamine isothiocyanate (TRITC)-conjugated porcine anti-rabbit $\operatorname{lgG}(1: 100)$, and TRITC-conjugated rabbit anti-mouse $\operatorname{lgG}(1: 100)$ were used as secondary antibodies. All samples were examined with a Nikon Fx epifluorescence photomicroscope (Nikon, Tokyo, Japan).

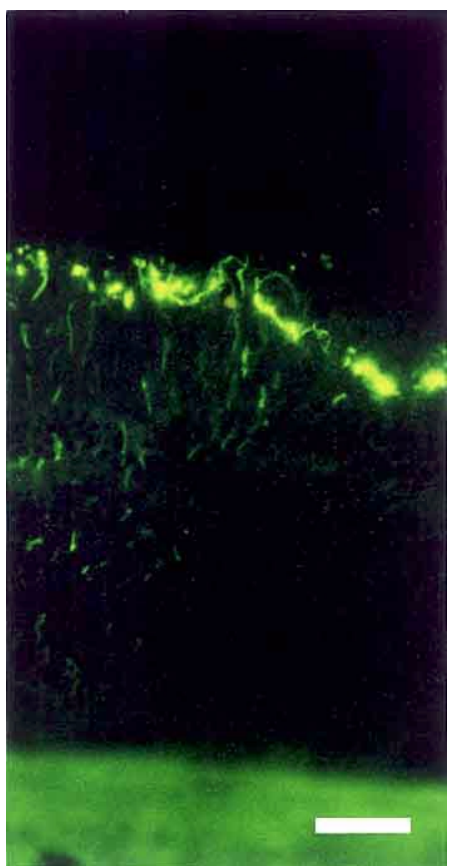

Fig. 2. Immunostaining GDNF. Bar:50 $\mu \mathrm{m}$. 


\section{Isolation and culture of porcine brain capillary endothelial cells}

Porcine brain capillary endothelial cells were purified by the procedure of Abbott et al. (1992) with slight modification (YamadaSasamori et al., 1997). Briefly, after peeling off the meninges and choroid plexus from brains obtained from miniature pigs weighing about $20 \mathrm{~kg}$, the cortical gray matter was carefully resected and minced with scissors into small pieces and digested in $0.25 \%$ dispase (Godo Shusei, Tokyo, Japan) and $0.12 \%$ collagenase (Yakult, Tokyo, Japan) in Ca- and Mg-free Hanks' balanced saline solution at $39^{\circ} \mathrm{C}$ for $60 \mathrm{~min}$. During the enzyme digestion, the solution containing the tissues was bubbled with a mixture of $95 \%$ $\mathrm{O}_{2}$ and $5 \% \mathrm{CO}_{2}$. After extensive pipetting, the capillaries were separated from the remaining slurry by centrifugation at $1,000 \times \mathrm{g}$ for $15 \mathrm{~min}$ in PBS containing $25 \%$ bovine serum albumin. After several rinses by centrifugation, fragments of capillaries were seeded onto 12-well tissue-culture plates coated with type IV collagen (Nitta Gelatin, Osaka, Japan) in Dulbecco's modified Eagle's medium 1:1 with Ham's F-12 nutrient mixture (Kyokuto, Tokyo, Japan), supplemented with $15 \%$ heat-inactivated fetal bovine serum (FBS; Morgate, Australia), $75 \mathrm{ng} / \mathrm{ml}$ insulin (Collaborative Biomedical, Bedford, MA, U.S.A.), $5 \mathrm{ng} / \mathrm{ml}$ transferrin (Collaborative Biomedical), $5 \mathrm{ng} / \mathrm{ml}$ selenous acid (Collaborative Biomedical), and $100 \mathrm{U} / \mathrm{ml}$ antibiotics. At day 1 after plating, $60 \mathrm{nM}$ vincristin (Sigma, St. Louis, MO, U.S.A.) was added to the cultures to eliminate undesirable cells until cell density reached subconfluence. The medium was renewed every other day. When the endothelial cells reached sub-confluence, they were released by $0.25 \%$ trypsin-EDTA (Gibco, Grand Island, NY, U.S.A.) and seeded at 25,000 cells/filter on $0.33 \mathrm{~cm}^{2}$ rat tail collagen-coated polycarbonate Coster Transwell filters $(0.4 \mathrm{~nm}$ pore size; Coster Corp., Cambridge, MA, U.S.A.). After passage, TER was measured every day to ascertain whether cell density reached confluence (Yamada-Sasamori et al., 1997). After 4-day cultivation without vincristin after passage, the medium of the endothelial cells was changed to medium containing NTN at various concentrations, $125 \mathrm{nM} \mathrm{8-(4-chlorophenylthio)} \mathrm{cAMP}$ (CPT-cAMP; Sigma) and $17.5 \mathrm{nM}$ phosphodiesterase inhibitor, R020-1724 (RBI, Natick, MA, U.S.A.).

\section{Measurement of transendothelial electrical resistance (TER)}

TER of endothelial cells on filters was measured using an Epithelial Voltohmmeter (World Precision Instruments, Sarasota, FL, U.S.A.) equipped with STX-2 $\mathrm{Ag} / \mathrm{AgCl}$ electrodes (World Precision Instruments). TER measurements were performed at $37^{\circ} \mathrm{C}$ on a thermal plate (Fine, Tokyo, Japan) after 8-hr treatment with the agents. TER was expressed in standard units of ohm $\times \mathrm{cm}^{2}$. For calculation of the resistance of endothelial cell monolayers, resistance of blank filters was subtracted from that of filters covered with cells. Each value was calculated from 5 or 6 cultures. Results are given as means $\pm \mathrm{SD}$. Differences between groups were tested by two-tailed Student's t test for unpaired data (Igarashi et al., 1999; Utsumi et al., 2000; Yamada-Sasamori et al., 1997).

\section{RESULTS}

Since GDNF is secreted from astrocytes, which are positive for GFAP, in the brain, the distribution of GDNF-producing cells was examined by double-immunostaining of GDNF and GFAP. Figs. 1A and 1B clearly demonstrate that GFAP-positive cells strongly reacted with antibody against GFAP. Figs. $1 \mathrm{C}$ and $1 \mathrm{D}$ also demonstrate that NTN was clearly detected in GFAP-positive cells. At higher magnification (Fig. 2), GDNF-positive cells were mainly localized in the inner layer of the neural retina and their processes were often seen in all layers of the neural retina, suggesting that GFAP-positive cells were a mixture of Müller cells and astrocytes in the retina, and secreted both GDNF and NTN.

Next, the localization of GFRs was examined by a double-immunostaining technique. Since GFR $\alpha 1$ is exclusively
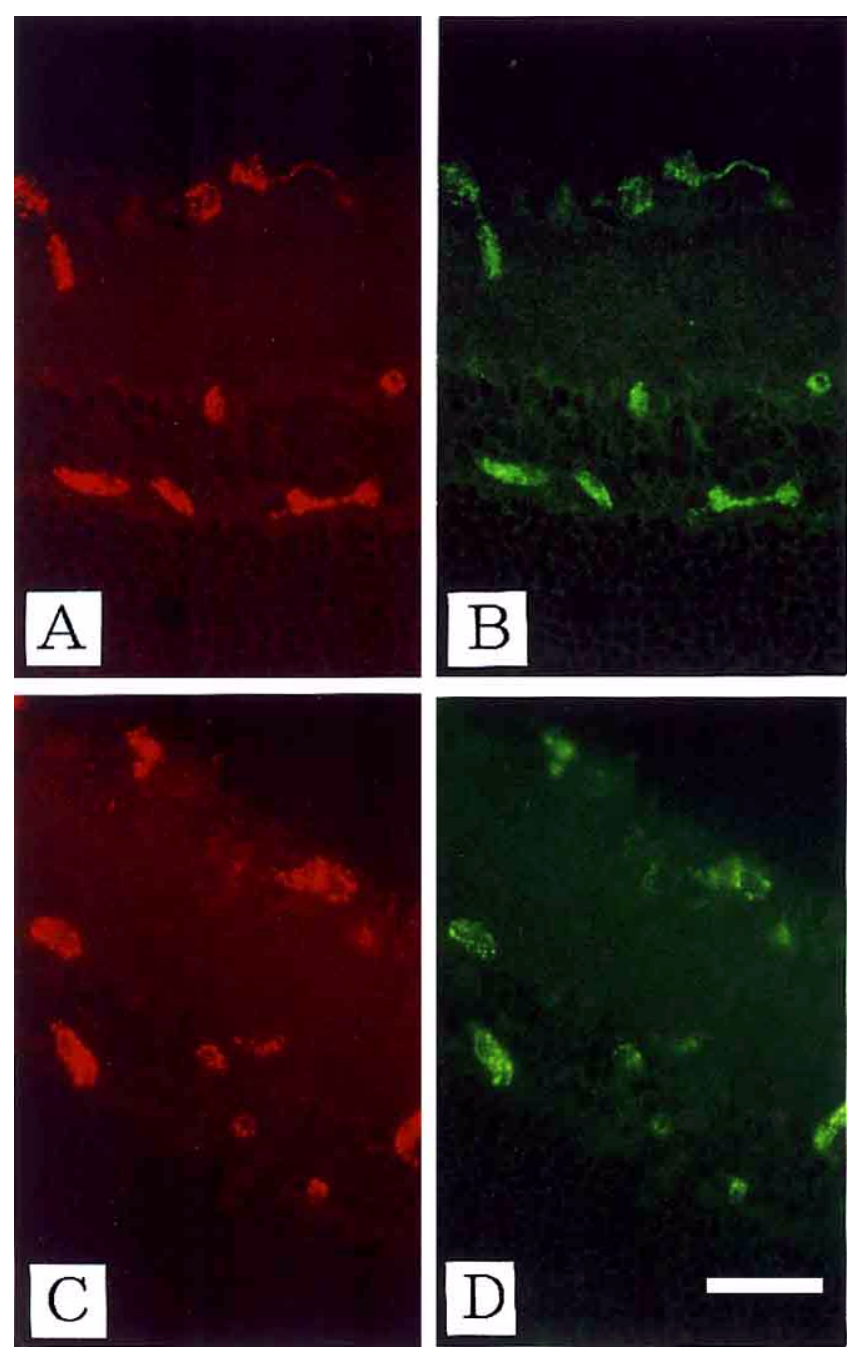

Fig. 3. Double-immunostaining of GFR $\alpha 1$ and GFR $\alpha 2$ with von Willebrand factor. A:von Willebrand factor, B: GFR $\alpha 1$, C: von Willebrand factor, D: GFR $\alpha 2$. Bar: $25 \mu \mathrm{m}$. 
Table I. Changes IN TER OF ENDOTHELIAL CELls FORMING THE BBB INDUCED BY 8-HR TREATMENT WITH GDNF, NTN AND/OR CAMP

\begin{tabular}{lc} 
& TER $\left(\mathrm{ohm} \times \mathrm{cm}^{2}\right)$ \\
\hline Control, before the treatment & $84.8 \pm 10.6$ \\
Control, after 8-hr incubation & $87.9 \pm 7.0$ \\
cAMP (CPT-cAMP+PDE-I) & $142.4 \pm 15.2^{*}$ \\
GDNF, $1 \mathrm{ng} / \mathrm{ml}$ & $83.6 \pm 7.6$ \\
GDNF, $1 / \mathrm{ng} / \mathrm{ml}+\mathrm{cAMP}$ & $263.6 \pm 20.0^{*, * *}$ \\
$\mathrm{NTN}, 1 \mathrm{ng} / \mathrm{ml}$ & $84.2 \pm 9.4$ \\
$\mathrm{NTN}, 1 \mathrm{ng} / \mathrm{ml}+\mathrm{cAMP}$ & $148.8 \pm 12.3^{*}$ \\
$\mathrm{NTN}, 10 \mathrm{ng} / \mathrm{ml}$ & $85.5 \pm 11.1$ \\
$\mathrm{NTN}, 10 \mathrm{ng} / \mathrm{ml}+\mathrm{cAMP}$ & $209.1 \pm 12.1^{*, * *}$ \\
\hline
\end{tabular}

Values (mean $\pm \mathrm{SD})$ were calcuated from 5 or 6 cultures.

* Significantly different from control $(\mathrm{p}<0.01)$.

**Significantly different from cAMP-supplemented cultures $(\mathrm{p}>0.01)$.

stained in the capillary endothelial cells of the brain cortex, von Willebrand factor was used as a marker for capillary endothelial cells of the retina. Figs. 3A-3D demonstrate that both GFR $\alpha 1$ and GFR $\alpha 2$ were detected in von Willebrand factor-positive cells, clearly showing that the capillary endothelial cells forming the inner BRB possessed these receptors for GDNF and NTN.

Since it is wellknown that the inner BRB shows very similar characteristics to the BBB, capillary endothelial cells obtained from bovine brain cortex were treated with GDNF or NTN, to ascertain whether NTN enhanced the barrier function of the BRB. NTN significantly increased the TER of the cells at a concentration of $10 \mathrm{ng} / \mathrm{ml}$ (Table I) under cAMP-supplemented conditions. Supplementation of cAMP alone also increased TER to some extent, which was considered to result from the induction of circumferential actin bundles (Lin et al., 1993; Trupp et al., 1999; Utsumi et al., 2000).

\section{Discussion}

The anatomical specialization of capillaries of the inner $\mathrm{BRB}$ is very similar to that of the BBB. In particular, astrocytes and/or Müller cells extend their processes to ensheath the capillaries. Astrocyte-conditioned medium has been reported to enhance barrier properties of the BBB (Janzer and Raff, 1987; Rubin et al., 1991) and Müller cells are considered to enhance those of the BRB (Carwile et al., 1998; Chunha-Vaz, 1976). Thus, the active participation of astrocytes in regulating the BRB has been postulated, although the molecular mechanism has yet to be clarified. Taking into consideration our previous finding that GDNF enhances the barrier function of endothelial cells forming the $\mathrm{BBB}$, the present findings strongly suggested that astrocytes and Müller cells regulate the BRB by secreting GDNF and/or NTN.

The results of double-immunostaining strongly suggested that both GDNF and NTN were produced and secreted from glial cells positive for GFAP in the retina. Of the retinal glial cells composed of Müller cells, astrocytes and microglia, we could not determine which cell type mainly secreted these factors. The GDNF- and NTN-positive cells with cellular processes extending into all layers of the neural retina like vines were judged to be Müller cells from their specific distribution and morphology.

Signals evoked by binding of GDNF and NTN to their receptors have been reported to be mediated through a multicomponent receptor complex consisting of tyrosine kinase type receptor Ret and either GFR $\alpha 1$ or GFR $\alpha 2$ (Baloh et al., 1998), respectively. However, capillaries forming the BBB and the BRB are immunohistochemically negative for Ret (Utsumi et al., 2000). Thus, the signal transduction systems of GDNF and NTN in endothelial cells are independent of Ret, as previously reported (Trupp et al., 1999).

The capillaries forming the inner BRB bear a close similarity in various aspects to those forming the BBB, except for fatty acid transport (Alberghina, 1998). Thus, the effects of GDNF and NTN on the function of tight junctions were examined using endothelial cells forming the porcine BBB. The present experiments clearly showed that NTN as well as GDNF significantly enhanced the barrier function of the endothelial cells forming the $\mathrm{BBB}$, although the effective concentration of NTN was 10 times higher than that of GDNF. We consistently failed to detect expression of NTN in the endothelial cells forming the BBB by RT-PCR and immunohistochemistry (data not shown). Since it is reported that NTN cross-reacts to GFR $\alpha 1$ specific for GDNF as well as GFR 2 specific for itself (Baloh et al., 1998), the difference in the effective concentration between GDNF and NTN may have occurred because the capillaries of BBB lack GFR $\alpha 2$. This is the first report that clearly shows that the capillaries of the BRB are positive for both GFR $\alpha 1$ and GFR $\alpha 2$, strongly suggesting that GDNF and NTN, which are secreted from glial cells, including Müller cells, regulate the barrier function of the BRB.

Acknowledgments. This study was supported in part by Grants-in-Aids from the Ministry of Education, Culture, Sports and Science, the Ministry of Welfare of Japan, and the Hokkaido Geriatrics Research Institute. We also thank Mr. Kim Barrymore for help with the manuscript.

\section{References}

Abbott, N.J., Hughes, C.C.W., Revert, P.A., and Greenwood, J. 1992. Development and characterization of a rat brain capillary endothelial culture: Towards an in vitro blood-brain barrier. J. Cell Sci., 103: 23-37

Alberghina, M. 1998. Fatty acid and lipid intermediate transport. In An Introduction to the Blood-Brain Barrier: Methodology, biology and 
pathology Pardridge, W.M., ed.), Cambridge University Press, Cambridge, pp.221-237.

Baloh, R.H., Tansey, M.G., Lampe, P.A., Fahrner, T.J., Enomoto, H., Simburger, K.S., Leitner, M.L., Araki, T., Johnson, E.M. Jr., and Milbrandt, J. 1998. Artemin, a novel member of the GDNF ligand family, supports peripheral and central neurons and signals through the GFR $\alpha 3-R E T$ receptor complex. Neuron, 21: 1291-1302.

Carwile, M.E., Culbert, R.B., Sturdivant, R.L., and Kraft, T.W. 1998. Rod outer segment maintenance is enhanced in the presence of bFGF, CNTF and GDNF. Exp. Eye Res., 66: 791-805.

Cunha-Vaz, J.G. 1976. The blood-retinal barrier. Doc. Ophthalmol., 41: 287-327.

Cunha-Vaz, J.G., Shikib, M., and Ashton, N. 1966. Studies on the permeability of the blood-retinal barrier. I. On the existence, development and site of a blood-retinal barrier. Br. J. Ophtalmol., 50: 441-453.

Durbec, P., Marcos-Gutierrez, C.V., Kilkenny, C., Grigoriou, M., Wartiowaara, K., Suvanto, P., Smith, D., Ponder, B., Costanini, F., Saarma, M., Sariola. H., and Pachnis, V. 1996. GDNF signaling through the ret receptor tyrosine kinase. Nature, 381: 789-793.

Henderson, C.E., Phillips, H.S., Pollock, R.A., Davies, A.M., Lemeulle, C., Armanini, M., Simpson, L.C., Moffet, B., Vandlen, R.A., Koliatsos, V.E., and Rosenthal, A. 1994. A potent survival factor for motoneurons present in peripheral nerve and muscle. Science, 266: 1062-1064.

Igarashi, Y., Utsumi, H., Chiba, H., Yamada-Sasamori, Y., Tobioka, H., Kamimura, Y., Furuuchi, K., Kokai, Y., Nakagawa, T., Mori, M., and Sawada, N. 1999. Glial cell line-derived neurotrophic factor induces barrier function of endothelial cells forming the blood-brain barrier. Biochem. Biophys. Res. Commun., 261: 108-112.

Janzer, R.C. and Raff, M.C. 1987. Astrocytes induce blood-brain barrier properties in endothelial cells. Nature, 325: 253-257.

Jing, S., Wen, D., Yu, Y., Holst, P.L., Luo, Y., Fang, M., Tamir, R., Antonio, L., Hu, Z., Cuppels, R., Louis, J.C., Hu, S., Altrock, B.W., and Fox, G.M. 1996. GDNF-induced activation of the ret protein tyrosine kinase is mediated by GDNFR- $\alpha$, a novel receptor for GDNF. Cell, $\mathbf{8 5}$ : 1113-1124.

Jomary, C., Thomas, M.,Grist, J., Milbrandt, J., Neal, M.J., and Jones, S.E. 1999. Expression patterns of neurturin and its receptor components in developing and degenerative mouse retina. Invest. Ophtalmol. Vis. Sci., 40: $568-574$.
Kotzbauer, P.T., Lampe, P.A., Heuckeroth, R.O., Golden, J.P., Creeden, D.J., Johnson, E.M. Jr., and Milbrandt, J. 1996. Neurturin, a relative of glial cell line-derived neurotrophic factor. Nature, 387: 467-470.

Lin, L.-F. H. Doherty, D.H., Lile, J.D., Bektesh, S., and Collins, F. 1993. GDNF: A glial cell line-derived neurotrophic factor for midbrain dopaminergic neurons. Science, 260: 1130-1132.

Rubin, L.L., Hall, D.E., Portes, S., Barbu, K., Cannon, C., Horner. H.C., Janatpour, M., Liaw, C.W., Manning, K., Morales, J., Tanner, L.I., Tomaselli, K.J., and Bard, F. 1991. A cell culture model of the bloodbrain barrier. J. Cell Biol., 115: 1725-1735.

Small, R.K., Watkins, B.A., Munro, P.M., and Liu, D. 1993. Functional properties of retinal Müller cells following transplantation to the anterior eye chamber. Glia, 7: 158-169.

Tout, S., Chan-Ling, T., Hollander, H., and Stone, J. 1993. The role of Müller cells in the formation of the blood-retinal barrier. Neuroscience, 55: 291-301.

Treanor, J.J.S., Goodman, L., Sauvage, F., Stone, D.M., Poulsen, K.T., Beck, C.D., Gray, C., Armanini, M.P., Pollock, R.A., Hefti, F., Buj-Bello, A., Davies, A.M., Asai, N., Takahashi, M., Vandlen, R., Henderson, C.E., and Rosenthal, A. 1996. Characterization of a multicomponent receptor for GDNF. Nature, 382: 80-83.

Trupp, M., Arenas, E., Fainzilber, M., Nilsson, A.S., Sieber, B.A., Grigoriou, M., Kilkenny, C., Salazer-Grueso, E., Pachnis, V., Arumäe, U., Sariola, H., Saarma, M., and Ibáñez, C.F. 1996. Functional receptor for GDNF encoded by the c-ret proto-oncogene. Nature, 381: 785-789.

Trupp, M., Scott, R., Whittemore, S.R., and Ibanez, C.F. 1999. Retdependent and -independent mechanisms of glial cel line-derived neurotrophic factor signaling in neuronal cells. J. Biol. Chem., 274: 2088520894.

Utsumi, H., Chiba, H., Kamimura, Y., Osanai, M., Igarashi, Y., Tobioka, H., Mori, M., and Sawada, N. 2000. Expression of GFRal, receptor for GDNF, in rat brain capillary during postnatal development of the BBB. Am. J. Physiol., 279: C361-C368.

Yamada-Sasamori, Y., Baba, T., Sawada, N., Tobioka, H., Isomura, H., Hashi, K., and Mori, M. 1997. Rapid induction of 7H6 tight junctionassociated protein and paracellular barrier function in capillary endothelial cells of porcine brain in vitro by treatment with astrocyte conditioned medium and cAMP. Med. Electron Microsc., 30: 8-14.

(Received for publication, July 21, 2000

and in revised form, August 18, 2000) 